\title{
Effect of individual characteristics on a mathematical model of human thermoregulation
}

Citation for published version (APA):

van Marken Lichtenbelt, W. D., Frijns, A. J. H., Fiala, D., Janssen, F. E. M., van Ooijen, A. M. J., \& van Steenhoven, A. (2004). Effect of individual characteristics on a mathematical model of human thermoregulation. Journal of Thermal Biology, 29, 577-581. https://doi.org/10.1016/j.jtherbio.2004.08.081

Document status and date:

Published: 01/01/2004

DOI:

10.1016/j.jtherbio.2004.08.081

Document Version:

Publisher's PDF, also known as Version of record

Document license:

Taverne

Please check the document version of this publication:

- A submitted manuscript is the version of the article upon submission and before peer-review. There can be important differences between the submitted version and the official published version of record.

People interested in the research are advised to contact the author for the final version of the publication, or visit the DOI to the publisher's website.

- The final author version and the galley proof are versions of the publication after peer review.

- The final published version features the final layout of the paper including the volume, issue and page numbers.

Link to publication

\footnotetext{
General rights rights.

- You may freely distribute the URL identifying the publication in the public portal. please follow below link for the End User Agreement:

www.umlib.nl/taverne-license

Take down policy

If you believe that this document breaches copyright please contact us at:

repository@maastrichtuniversity.nl

providing details and we will investigate your claim.
}

Copyright and moral rights for the publications made accessible in the public portal are retained by the authors and/or other copyright owners and it is a condition of accessing publications that users recognise and abide by the legal requirements associated with these

- Users may download and print one copy of any publication from the public portal for the purpose of private study or research.

- You may not further distribute the material or use it for any profit-making activity or commercial gain

If the publication is distributed under the terms of Article $25 \mathrm{fa}$ of the Dutch Copyright Act, indicated by the "Taverne" license above, 


\title{
Effect of individual characteristics on a mathematical model of human thermoregulation
}

\author{
W.D. van Marken Lichtenbelt ${ }^{\mathrm{a}, *}$, A.J.H. Frijns ${ }^{\mathrm{b}}$, D. Fiala ${ }^{\mathrm{c}}$, F.E.M. Janssen ${ }^{\mathrm{b}}$, \\ A.M.J. van Ooijen ${ }^{\mathrm{a}}$, A.A. van Steenhoven ${ }^{\mathrm{b}}$ \\ ${ }^{a}$ Department of Human Biology, Maastricht University, PO Box 616, Maastricht, The Netherlands \\ ${ }^{\mathrm{b}}$ Department of Energy Technology, Eindhoven University of Technology, Eindhoven, The Netherlands \\ ${ }^{\mathrm{c}}$ Institute of Energy and Sustainable Development, De Montfort University, Leicester, UK
}

\begin{abstract}
A multi-segmental mathematical model of human thermoregulation was tested for its capability to predict individualized physiological responses. We compared the model predictions obtained for an average person with measured individual responses of subjects exposed to mild cold. Secondly, body composition (BC) data, the resting metabolic rate (MR), and the actual measured MR during the test were used as input into the model.

The data was obtained from 20 subjects (age: 19-36 years; BMI: $17-32 \mathrm{~kg} / \mathrm{m}^{2}$ ). BC, MR, rectal and skin temperatures were measured for $1 \mathrm{~h}$ at $22^{\circ} \mathrm{C}$, followed by $3 \mathrm{~h}$ at $15^{\circ} \mathrm{C}$.

A mean bias of $1.8^{\circ} \mathrm{C}$, with a standard error of $0.7^{\circ} \mathrm{C}$, resulted for the mean skin temperature of an average person at $15^{\circ} \mathrm{C}$. When subjective $\mathrm{BC}$ and measured MR were incorporated the bias was $-0.2 \pm 0.9^{\circ} \mathrm{C}$. For the hand-back skin temperature the bias \pm standard error fell from $5.3 \pm 2.8^{\circ} \mathrm{C}$ for an average person to $2.0 \pm 2.5^{\circ} \mathrm{C}$, when using individualized characteristics. Trunk skin temperatures were not significantly affected by the adjustments.

In conclusion, this study shows that on a group level predictions of skin temperatures can be improved when adopting individualized body characteristics and measured MR, but the predictions on an individual level were not improved. (C) 2004 Elsevier Ltd. All rights reserved.
\end{abstract}

Keywords: Body temperature; Energy expenditure; Body composition

\section{Introduction}

In daily life humans are frequently exposed to environmental conditions that deviate from thermoneutral conditions. Disturbances from thermo-neutral conditions can lead to temporal changes in the body heat content and to adjustments of the thermoregulatory system. Even under mild environmental conditions,

\footnotetext{
*Corresponding author. Tel.: +31-43-3881-629; fax: + 3143-3670-976.

E-mail address: markenlichtenbelt@hb.unimaas.nl (W.D. van Marken Lichtenbelt).
}

individuals may differ in their physiological response (Marken Lichtenbelt et al., 2002; Marken Lichtenbelt et al., 2001). Inter-individual differences in the thermoregulatory responses to severe cold, for instance, have been linked to age, the composition of the body and the sex (Kaciuba-Uscilko and Grucza, 2001; Matsumoto et al., 1999; Van Someren et al., 2002). Under mild cold conditions comparably little information is available. Recent research, however seems to indicate that the body composition (BC) is an important factor (Ooijen et al., 2004).

Since the 1960s various mathematical models have been developed to enlarge our understanding of the 
principles of human thermoregulation (Stolwijk, 1971). Other heat budget models have been used, for example, to predict occupant comfort in buildings equipped with heating and air conditioning systems (Fanger, 1973). A promising potential application for mathematical models of human heat transfer and thermal comfort is in the clinic (e.g. surgery/recovery (Sessler, 2000); accidental hypothermia; pre-terms (Horn et al., 2002)) and in health sciences (differences in metabolic efficiency between subjects groups (Matsumoto et al., 1999)).

Most of the models available today are based on the work of Stolwijk (1971), who modeled the body as a composite of several cylinders representing the head, the corpus, and the upper and lower extremities. Useful refinements of this model have been implemented, among others by Wissler and Huizinga (Huizinga et al., 2001; Wissler, 1985). However, most thermoregulary models have been postulated on the basis of a limited number of experiments and often the authors have used their own experiments to validate their models. Fiala et al. (1999) have developed a new model based on the analysis of a large number of independent experimental data.

The purpose of this study was to investigate possibilities and potential of the model to also predict interindividual differences in human body temperature and metabolic responses to cold. Firstly, we compared predictions of the original model for a standard subject with measured individual responses to mild cold. Secondly, the model was adopted to incorporate individualized characteristics (BC data, resting metabolic rate (RMR)) and actual measured metabolic rate (MR) during the test.

\section{Methods}

\subsection{Measurements}

\subsubsection{Design}

The experiments took place at the end of the summer, in August and September. The subjects attended the laboratory for an overnight stay including the following morning to participate in the experiment. The subjects were instructed to perform no exercise the day before the measurement and they were in fasting condition. In the morning, MR, intestinal, rectal and skin temperatures were measured for $1 \mathrm{~h}$ at an ambient temperature of $22^{\circ} \mathrm{C}$ followed by $3 \mathrm{~h}$ during which the subjects were exposed to $15{ }^{\circ} \mathrm{C}$. Relative humidity was $50 \%$ and ventilation was $0.05 \mathrm{~m} / \mathrm{s}$. The subjects were lying supine on a stretcher. The clothing, with an overall insulation of $I_{\mathrm{cl}}=0.71 \mathrm{clo}$ $\left(R_{\mathrm{cl}}=0.109 \mathrm{~m}^{2}{ }^{\circ} \mathrm{C} / \mathrm{W}\right)$, consisted of sweatpants $(0.28 \mathrm{clo})$, a sweater $(0.37 \mathrm{clo})$, socks $(0.02$ clo $)$ and panties and a bra for women and briefs for men $(0.04 \mathrm{clo})$. In the experiment, the face, hands and ankles were uncovered.

\subsubsection{Subjects}

Ten male and 10 female subjects between 19 and 36 years of age and BMI ranging from 17 to $32 \mathrm{~kg} / \mathrm{m}^{2}$ participated in the experiment. Percentage fat was significantly higher $(27 \pm 7 \%)$ in females compared to males $(16 \pm 8 \%)$. With respect to thermoregulatory responses and MR, corrected for fat-free mass, there were no significant gender differences. The subjects were non-smokers and were not on medication.

The volunteers were given detailed information regarding the purpose and the methods used in the study, before written consent was obtained. The Ethics Committee of Maastricht University approved the study.

\subsubsection{Methods}

BC was calculated using the three-compartment model according to Siri (1956), using underwater weighing and deuterium dilution (Westerterp et al., 1995).

During the morning tests, the $\mathrm{O}_{2}$ consumption and the $\mathrm{CO}_{2}$ production were measured by indirect calorimetry, using a ventilated hood system. MR was calculated from this data according to Weir (1949). RMR was defined as the MR in a thermo-neutral environment, lying still and awake.

Rectal temperature was measured continuously by a thermistor-probe (YSI probes, series 402, Yellow Springs Instruments Co. Ltd., Ohio, U.S.A.) inserted for $10 \mathrm{~cm}$.

Skin temperatures were measured by surface thermistors (YSI probes, series 409B), at the handback, upper arm, chest at the $\mathrm{m}$. pectoralis, abdomen anterior, back, thigh anterior, and foot instep. Temperatures were recorded continuously for $50 \mathrm{~s}$ out of every minute and saved every minute.

\subsection{Modeling}

The model we used was developed to predict human physiological and perceptual responses in both steady state and transient conditions (Fiala et al., 1999,2001). The dynamic model of human thermoregulation consists of a passive- and active-system model and predicts body temperatures, regulatory responses and components of the environmental heat loss in cold stress, cool, neutral, warm and hot stress conditions. It consists of a passive heat transfer part and an active thermoregulatory part. The passive system of the model - a multi-segmental (14 cylinders in combination with a sphere for the head), multilayered (4-5 tissue layers per body element) representation of the human body with spatial subdivisions accounts for phenomena of human heat transfer within the body and at its surface. Within the body thermal effects of blood circulation, heat-generation, -conduction and -accumulation are considered. At the 
surface the effects of convection, radiation, clothing insulation, skin moisture-evaporation, -diffusion, and accumulation are taken into account.

The active system simulates the thermoregulatory reactions of the central nervous system in response to changes in the body temperature distribution. The body can respond by extra heat production (shivering, metabolic heat production), sweating, and vasomotion.

The thermoregulatory part of model was developed based on regression analysis using a large number of published experiments to mimic the 'average' human thermoregulatory behavior.

The passive system represents a standard male subject with the following characteristics: $73.5 \mathrm{~kg}$ body weight, $1.71 \mathrm{~m}$ height, $14.4 \%$ fat, $1.86 \mathrm{~m}^{2}$ skin surface area, $6 \%$ wetted skin area ratio, $4.9 \mathrm{~L} / \mathrm{min}$ cardic output, and $87.1 \mathrm{~W}$ basal MR.

The model requires input data on the thermal environment, the activity level, and the clothing insulation for which the thermal state of the body will be predicted.

\subsection{Model measurement comparisons}

Firstly, we compared the predictions obtained for an average subject with measured individual thermoregulatory responses to mild cold, using the standard input procedures.

Secondly, we included in the model actual measured MR throughout the cold exposure test, RMR, and/or $\mathrm{BC}$ data (i.e. height, weight and percent body fat).
We calculated the differences between predictions of the model with measured results for each individual over $1 \mathrm{~min}$ periods. These were used to calculate mean differences and standard deviations (SD). The results are provided as mean $\pm \mathrm{SD}$ over $30 \mathrm{~min}$. time intervals, i.e. the last $30 \mathrm{~min}$ in comfort $\left(22^{\circ} \mathrm{C} ; 31-60 \mathrm{~min}\right)$ and the last $30 \mathrm{~min}(211-240 \mathrm{~min})$ in the cold $\left(15^{\circ} \mathrm{C}\right.$; Table 1).

\section{Results}

Using the standard modeling procedure differences between model and measurement are substantial, i.e. up to $5.3 \pm 2.8^{\circ} \mathrm{C}$ (handback) during the last $30 \mathrm{~min}$ interval (Table 1). As an example, the deviation between predicted and measured mean skin temperature is plotted over time in Fig. 1. Adopting individual characteristics (RMR and BC) and actual MR in the model, improved the predictions of skin temperatures to a notable extent for most body parts. For instance, the improvement was substantial during the last $30 \mathrm{~min}$ in the cold for mean skin temperature (from 1.8 to $-0.15^{\circ} \mathrm{C}$ ) and the handback temperature (from 5.26 to $1.98^{\circ} \mathrm{C}$ ) (Table 1). Also improved predictions of the rectal temperature were obtained although the predictions were already within the measurement error. The SD did not change much. For the skin temperatures the main improvements achieved were due to the combined effect of correction for BC and actual measured MR. The effect of a variable RMR in the model on predicted

Table 1

Mean temperature difference $\left({ }^{\circ} \mathrm{C}\right)$ and standard deviation between model and measurement for mean skin temperature and at four body locations

\begin{tabular}{|c|c|c|c|c|c|c|c|c|c|c|c|}
\hline \multirow{2}{*}{$\begin{array}{l}\text { Time } \\
\text { interval } \\
(\mathrm{min})\end{array}$} & \multirow{2}{*}{$\begin{array}{l}\text { Modeling } \\
\text { procedure }\end{array}$} & \multicolumn{2}{|l|}{ Mean skin } & \multicolumn{2}{|c|}{ Foot anterior } & \multicolumn{2}{|c|}{ Hand posterior } & \multicolumn{2}{|c|}{ Abdomen posterior } & \multicolumn{2}{|l|}{ Rectal } \\
\hline & & difference & SD & difference & $\mathrm{SD}$ & difference & SD & difference & $\mathrm{SD}$ & difference & $\mathrm{SD}$ \\
\hline $31-60$ & Standard & 0.86 & 0.59 & -1.17 & 1.53 & 1.62 & 2.05 & 0.52 & 0.75 & 0.32 & 0.33 \\
\hline $211-240$ & & 1.78 & 0.67 & 2.63 & 1.67 & 5.26 & 2.76 & -0.57 & 1.18 & -0.13 & 0.43 \\
\hline $31-60$ & RMR input & 0.87 & 0.58 & -1.20 & 1.53 & 1.68 & 2.05 & 0.53 & 0.75 & 0.36 & 0.32 \\
\hline $211-240$ & & 1.67 & 0.66 & 2.48 & 1.62 & 5.13 & 2.78 & -0.55 & 1.19 & -0.02 & 0.37 \\
\hline $31-60$ & MR input & 0.14 & 0.59 & -1.86 & 1.52 & 1.23 & 1.97 & 0.25 & 0.76 & 0.60 & 0.33 \\
\hline $211-240$ & & 0.61 & 0.68 & 1.14 & 1.66 & 3.99 & 2.55 & -0.69 & 1.20 & 0.62 & 0.44 \\
\hline $31-60$ & BC input & 0.12 & 0.76 & -1.98 & 1.51 & 0.87 & 2.08 & -0.10 & 0.93 & -0.17 & 0.73 \\
\hline $211-240$ & & 0.86 & 1.03 & 1.87 & 1.63 & 4.27 & 2.58 & -1.30 & 1.49 & -0.55 & 0.83 \\
\hline $31-60$ & $\mathrm{BC}$ and $\mathrm{RMR}$ & 0.12 & 0.77 & -1.93 & 1.53 & 0.90 & 2.09 & -0.09 & 0.92 & -0.13 & 0.72 \\
\hline $211-240$ & input & 0.79 & 1.03 & 1.80 & 1.64 & 4.16 & 2.59 & -1.25 & 1.48 & -0.43 & 0.77 \\
\hline $31-60$ & $\mathrm{BC}$ and $\mathrm{MR}$ & -0.58 & 0.75 & -2.59 & 1.49 & 0.04 & 2.10 & -0.38 & 0.93 & 0.08 & 0.77 \\
\hline $211-240$ & input & -0.15 & 0.89 & 0.62 & 1.60 & 1.98 & 2.54 & -1.33 & 1.40 & 0.09 & 0.87 \\
\hline
\end{tabular}

RMR: resting metabolic rate; MR: metabolic rate; BC: body composition; SD: standard deviation. 


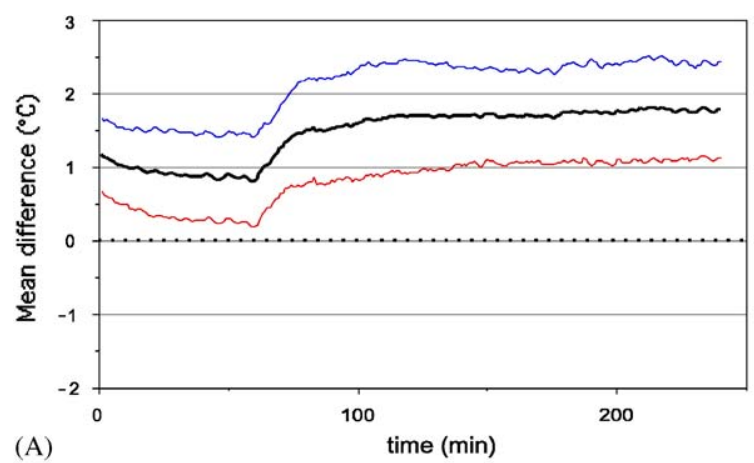

(A)

time (min)

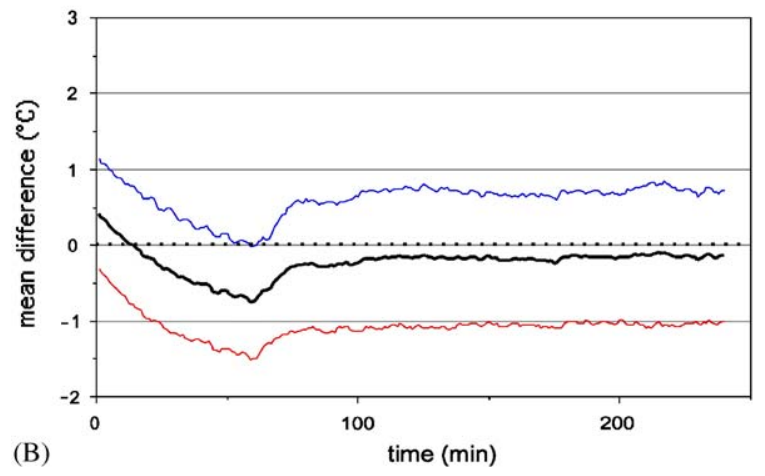

Fig. 1. (A) Mean difference (bold line) with SD (thin line) between modeled and measured skin temperature plotted against time, using the standard subject in the model (B) and with input in the model of subject characteristics and actual measured MR.

temperatures was negligible. The largest improvements resulted from the inclusion of the measured MR throughout the test.

The predicted skin temperature of the trunk were found to be less sensitive changing individual characteristics, as can be seen for the abdomen posterior in Table 1. Results from the thorax anterior and abdomen anterior showed similar results (not provided in here).

\section{Discussion}

In this study, the Fiala multi-segmental thermoregulatory model was used to predict the average human physiological responses and showed discrepancies to measured responses of individuals exposed to comfortable and mild cold environmental conditions. However, corrections for individual characteristics of healthy subjects showed that the model could be improved substantially on group level (mean deviation). The effect was largest on the exposed body elements, because the variation in temperature is the largest on these parts.

Deviations on an individual level still remain large (large SD).
Improvement of the model was the largest by adopting the actual, measured metabolism throughout the test. This is in itself not surprising since the model gets adapted along the modeling process. However, it indicates the necessity of improving the model with respect to changes in energy metabolism in response to mild cold.

When accurate predictions on an individual level are needed or predictions in the clinic under special thermal conditions (hypothermia, hyperthermia, anaeasthesia, etc.) are needed, adaptations of the model are likely to be necessary. Here, a model with more physiological background could be used in place of the regression model implemented in the active system part of the model. The target for future research is beside a correction for individual characteristics, also integration of physiological based control-mechanisms in the model.

\section{References}

Fanger, P.O., 1973. Thermal Comfort-Analyses and Applications in Environmental Engineering. McGraw-Hill, New York, pp. 244.

Fiala, D., Lomas, K.J., Stohrer, M., 1999. A computer model of human thermoregulation for a wide range of environmental conditions: the passive system. J. Appl. Physiol. 87, 1957-1972.

Fiala, D., Lomas, K.J., Stohrer, M., 2001. Computer prediction of human thermoregulatory and temperature responses to a wide range of environmental conditions. Int. J. Biometeorol. $45,143-159$.

Horn, E.P., Schroeder, F., Gottschalk, A., Sessler, D.I., Hiltmeyer, N., Standl, T., Schulteam Esch, J., 2002. Active warming during cesarean delivery. Anesth. Analg. 94, 409-414, table of contents.

Huizinga, C., Zang, H., Arens, E., 2001. A model of human physiology and comfort for assessing complex thermal environments. Build. Environ. 36, 691-699.

Kaciuba-Uscilko, H., Grucza, R., 2001. Gender differences in thermoregulation. Curr. Opin. Clin. Nutr. Metab. Care 4, 533-536.

Marken Lichtenbelt, W.D.v., Westerterp-Plantenga, M.S., Van Hoydonk, P., 2001. Individual variation in the relation between body temperature and energy expenditure in response to elevated ambient temperature. Physiol. Behav. 73, 235-242.

Marken Lichtenbelt, W.D.v., Schrauwen, P., Kerckhove, S.v.d., Westerterp-Plantenga, M.S., 2002. Individual variation in body temperature and energy expenditure in response to mild cold. Am. J. Physiol. 282, E1077-E1083.

Matsumoto, T., Miyawaki, T., Ue, H., Kanda, T., Zenji, C., Moritani, T., 1999. Autonomic responsiveness to acute cold exposure in obese and non-obese young women. Int. J. Obes. Relat. Metab. Disord. 23, 793-800.

Ooijen, A.M.J., Marken Lichtenbelt, W.D.v., Steenhoven, A.A., Westerterp, K., 2004. Seasonal changes in metabolic and temperature responses to cold air in humans. Physiol. Behav 82, 545-553. 
Sessler, D.I., 2000. Perioperative heat balance. Anesthesiology 92, 578-596.

Siri, W.E., 1956. The gross composition of the body. In: Tobias, C.A., Lawrence, J.H. (Eds.), Advances in Biological and Medical Physics, vol. 4. Academy Press, New York, pp. 239-280.

Stolwijk, J.A.J., 1971. A mathematical model of physiological temperature regulation in man. NASA, Washington DC.

Van Someren, E.J., Raymann, R.J., Scherder, E.J., Daanen, H.A., Swaab, D.F., 2002. Circadian and age-related modulation of thermoreception and temperature regulation: mechanisms and functional implications. Aging Res. Rev. 1, 721-778.
Weir, J.B., 1949. New methods for calculating metabolic rate with special reference to protein metabolism. J. Physiol. 109, $1-9$.

Westerterp, K.R., Marken Lichtenbelt, W.D.v., Wouters, L., 1995. The Maastricht protocol for the measurement of body composition and energy expenditure with labeled water. Obes. Res. 3, 49-57.

Wissler, E.H., 1985. Mathematical simulation of human thermal behavior using whole body models. In: Shitzer, A., Eberhart, R.C. (Eds.), Heat Transfer in Medicine and Biology, Analysis and Applications, vol. 1. Plenum Press, New York, pp. 325-373. 